Outros Tempos, vol. 18, n. 32, 2021, p. 220-247. ISSN: 1808-8031

DOI: http://dx.doi.org/10.18817/ot.v18i32.857

\title{
AS VIVÊNCIAS MUSICAIS DA CAPITAL MARANHENSE SOANDO NOS JORNAIS OITOCENTISTAS $(1850-1900)^{1}$
}

THE MUSICAL EXPERIENCES OF THE MARANHENSE CAPITAL RESOUNDING IN THE EIGHTEENTH-CENTURY NEWSPAPERS (1850 -1900)

\section{LAS VIVENCIAS MUSICALES DE LA CAPITAL MARANHENSE SONANDO EN LOS PERIÓDICOS OCHOCENTISTAS (1850 - 1900)}

\author{
JOÃO COSTA GOUVEIA NETO \\ ORCID: https://orcid.org/0000-0001-7202-7198 \\ Doutorando em Educação (UFPA) \\ Professor do Curso de Licenciatura em Música da Universidade Estadual do Maranhão \\ São Luís/Maranhão/Brasil \\ rairicneto@yahoo.com.br
}

\begin{abstract}
Resumo: Este artigo tem por objetivo apresentar as vivências musicais ludovicenses entre 1850 e 1900, a partir dos anúncios vinculados em jornais que circulavam na capital maranhense. Nesse sentido, vivências musicais são um conjunto de práticas e representações relacionadas ao ato de frequentar os teatros, os bailes, as festas religiosas e cíveis, possuir e tanger um instrumento musical, participar de aulas de músicas dentre outros. Todas essas práticas estavam relacionadas aos modelos europeus de divertimento e elegância que as elites ludovicenses desejavam seguir e a partir das quais organizavam seus relacionamentos sociais.
\end{abstract}

Palavras-chave: Vivências musicais. Jornais. Século XIX.

\begin{abstract}
This article aims to present the ludovicenses musical experiences between 1850 and 1900, based on the advertisements attached to the newspapers that circulated in the capital of Maranhão. In this sense, musical experiences are a set of practices and representations related to the act of attending theaters, dances, religious and civil parties, owning and playing a musical instrument, participating in music classes, among others. All of these practices were related to the European models of fun and elegance that ludovicense elites wished to follow, and from which they organized their social relationships.
\end{abstract}

Keywords: Musical experiences. Newspapers. $19^{\text {th }}$ Century.

Resumen: Este artículo tiene como objetivo presentar las vivencias musicales ludovicenses entre 1850 y 1900, a partir de los anuncios enlazados en los periódicos que circularon en la capital del estado de Maranhão. En este sentido, las vivencias musicales son un conjunto de prácticas y representaciones relacionadas con el acto de asistir a teatros, bailes, fiestas religiosas y civiles, poseer y tocar un instrumento musical, participar en clases de música, entre otros. Todas estas prácticas estaban relacionadas con los modelos europeos de diversión y elegancia que las élites ludovicenses deseaban seguir y a partir de los cuales organizaron sus relaciones sociales.

Palabras clave: Vivencias musicales. Periódicos. Siglo XIX.

\footnotetext{
${ }^{1}$ Artigo submetido à avaliação em abril de 2021 e aprovado para publicação em junho de 2021.
} 
Outros Tempos, vol. 18, n. 32, 2021, p. 220-247. ISSN: 1808-8031

\section{Introdução}

Discorrer sobre a importância da imprensa na atualidade é um tema pulsante e em movimento constante. No entanto, é consenso entre os historiadores que toda fonte de estudo necessita de uma periodização clara a fim de se evitar erros historiográficos. Nesse sentido, é fundamental interpretar o objeto à luz do contexto de produção da sua escrita. Deste modo, “[...] a imprensa é importante para o historiador, pois é rica em dados e elementos, e para alguns períodos é a única fonte de reconstituição histórica, permitindo um melhor conhecimento da sociedade ao nível de suas condições de vida, manifestações culturais e políticas" (ZICMAN, 1985, p. 90 apud OLIVEIRA, 2011, p. 128).

Dessa maneira, os jornais devem ser arrolados no grupo mais amplo dos periódicos que inclui os boletins, os almanaques, os catálogos e as revistas (BARROS, 2019, p. 179). Ainda segundo o referido autor, as revistas “[...] rivalizam em importância com os jornais diários, constituindo ambos os principais modelos básicos de periódicos dos quais, de alguma maneira, todos os outros derivam ou se aproximam" (BARROS, 2019, p. 179-180). Para a análise das vivências musicais dos últimos oito anos do século XIX maranhense é possível utilizar, por exemplo, a Revista Elegante ${ }^{2}$, uma vez que apresenta em suas páginas anúncios e notícias sobre o movimento artístico. No entanto, os jornais apresentam mais quantidade de informações, pois são constituídos por um conjunto de textos, que formam uma "polifonia de textos" (BARROS, 2019, p. 184). Assim, entendo como os autores que, para analisar os aspectos culturais e várias camadas dos aspectos sociais, a utilização da imprensa, no caso deste artigo, em específico, o uso dos jornais é imprescindível.

Na complexa sociedade ludovicense da segunda metade do século XIX, não era diferente, os homens e as mulheres, sendo pobres ou ricos, buscavam por lugares, objetos, símbolos, formas de comportamento, tipos de leitura, arquitetura, pintura que tivessem referências com seus hábitos e costumes, e assim servissem para identificá-los como membros de uma determinada comunidade, pois “[...] à 'boa sociedade' a europeização da vida social, o que incluía uma sociabilidade baseada nas festas particulares e nos salões [...]" (RAINHO, 2002, p. 54). Dependendo do lugar e do tempo nos quais estes homens e mulheres estão inseridos essas formas de identificar se modificam, são readaptadas a fim de adequarem-se às necessidades do convívio social. Para a sociedade elitista do referido período não foi diferente, pois

\footnotetext{
${ }^{2}$ A Revista Elegante pode ser consultada no acervo digital da Biblioteca Pública Benedito Leite (BPBL), disponível em http://casas.cultura.ma.gov.br/portal/bpbl/acervodigital/.
} 
Outros Tempos, vol. 18, n. 32, 2021, p. 220-247. ISSN: 1808-8031

[...] com a formação de uma camada social burguesa que passa a compor o poder com os senhores territoriais e o consequente desenvolvimento da vida urbana se estabelece o contexto da sociedade oficial, que se esmerava na imitação dos valores sociais e culturais importados da Europa (FONSECA, 1996, p. 12).

Toda essa movimentação e estratégias relacionadas às regras, aos hábitos e aos valores sociais tiveram os jornais como importantes locais de propagação durante o século XIX.

Um dos requisitos para um membro das elites ser considerado culto e refinado era possuir além dos conhecimentos clássicos adquiridos nas escolas de ensino regular, algum conhecimento de artes ou algo do gênero, que o diferenciaria dos demais de seu estrato social e dos outros setores desprivilegiados da sociedade. Um desses conhecimentos, que podia ser adquirido nas escolas regulares ou com professores particulares, era o musical. A música, desde os tempos mais antigos, serviu para diferenciar uns e como instrumento de barganha para outros. Na capital maranhense, a música e os músicos também eram tidos em alta estima.

No século XIX, os membros das elites quando se dedicavam à música era a linguagem musical formal que tem como características a escrita em partitura, leitura rítmica e solfejo musical. Esse aprendizado era qualificado como um ornamento que os filhos das elites apresentavam e que os diferenciavam dos demais. Para as mulheres de elite a música qualificava essa moça casadoira, pois a "[...] lição de piano é referida como uma obrigação de rotina, sendo atividade contígua à de coser e bordar, cumprida sob o controle da família" (FONSECA, 1996, p. 75).

Já para os homens, além da herança e do nome de família tradicional que herdavam, a música era uma forma de conquistar sua futura esposa sem precisar ter contato físico com ela, devido ao cuidado quase carcerário que as famílias tinham com as moças, guardadas nos grandes palacetes coloniais. Assim, “[...] além de ser utilizada para 'agradar as mulheres' com os seus 'corações ternos e doces', a música funcionava também como indicativo do grau de sociabilidade e civilidade dos cortesãos" (MONTEIRO, 2008, p. 86). Dessa forma, a música deve ser entendida como um fenômeno social e que tem implicações na sociedade onde é produzida e consumida.

Nesse sentido, as vivências musicais são um conjunto amplo de práticas e representações (CHARTIER, 1990) relacionado à presença durante as apresentações nos teatros, nos bailes, nas festas religiosas, na existência de professores ministrando aulas de música, na venda de instrumentos musicais, dentre outros eventos nos quais a música conduzia a movimentação das pessoas. 
Outros Tempos, vol. 18, n. 32, 2021, p. 220-247. ISSN: 1808-8031

Para analisar a presença da música e das vivências musicais na capital maranhense utilizarei os jornais A Flecha (1879-1880), A Imprensa (1857-18??), A Nova Epocha (185618??), A Moderação (1857-18??), Correio d'Annuncios (1851-1862), Diário do Maranhão (1855-1911), Jornal do Commercio (1858-18??), O Apreciável (1866-18??), O Domingo (1872-18??), O Observador (1847-18??), O Paiz (1863-18??), Pacotilha (1880-1938), Porto Livre (1862-18??) e Publicador Maranhense (1842-1886), pois eles são fontes privilegiadas para o estudo do século XIX, visto que, para além das discussões já tratadas sobre seu uso como fonte histórica (LUCA, 2008), indicam os sons individuais e coletivos que constituíam a São Luís Oitocentista. Nesse sentido, este artigo tem por objetivo mostrar a potencialidade dos jornais como fonte e meio de informação e comunicação relacionado às vivências musicais.

\section{Os espaços das vivências musicais nos jornais}

O culto à prática musical foi difundido nas cortes imperiais, mas ao longo do século XVIII e, principalmente, XIX passou a ser desenvolvida pelas famílias aristocráticas e pela nascente classe burguesa em busca de status social. Esses homens conhecedores das letras e agora das artes musicais foram os diletantes das sociedades imperiais, sendo "[...] alfabetizados em música, sem, no entanto, serem músicos, apropriam-se da nomenclatura musical seja instrumental ou de elementos, para criar um corpo de crítico musical" (NEVES, 2000, p.178), sendo ainda um “[...] aficionado do teatro lírico, algumas vezes é cantor amador, entende e domina todos os meandros da música clássica e da ópera [...]” (NEVES, 2000, p. 178).

$\mathrm{Na}$ capital maranhense não foi diferente das demais cidades do Brasil. O teatro mais importante do Maranhão foi construído a partir de uma iniciativa particular dos empresários Eleutério Lopes da Silva Varela e Estevão Gonçalves Braga, e inaugurado em 1817, com o nome de Teatro União, recordando a união do Brasil com Portugal antes da sua independência (MARQUES, 1970, p. 596). Após a sua inauguração, o Teatro União ofereceu aos maranhenses divertimentos dos mais variados gêneros, conforme historiciza Jansen (1974) ao narrar década a década o movimento teatral, inclusive a programação do referido teatro.

No entanto, a maior quantidade de espetáculos dados no Teatro União será a partir de 1850. Nesse ano o Publicador Maranhense veiculou o anúncio a seguir: 
Outros Tempos, vol. 18, n. 32, 2021, p. 220-247. ISSN: 1808-8031

Figura 1 - Theatro União

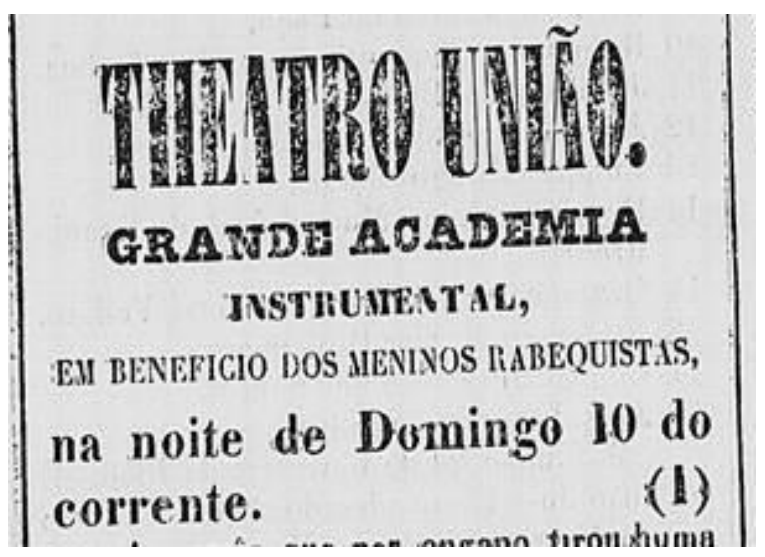

Fonte: Publicador Maranhense, ano 8, n. 9817, 7 mar. 1850. p. 4.

Apesar do espetáculo apresentado, o Teatro União precisava de reformas urgentes com as quais os seus donos não podiam arcar; desse modo, o governo da província do Maranhão comprou a parte dos herdeiros dos empresários e realizou as obras necessárias no prédio. O Teatro foi fechado em agosto de 1850 e reaberto em 14 de março de 1852 , rebatizado com o nome de Teatro São Luís ${ }^{3}$. Durante todo o restante do ano de 1852, o público maranhense pôde assistir árias de óperas de Guiseppe Verdi (1813-1901) e Gaetano Donizetti (1797-1848) (GOUVEIA NETO, 2010). Já no ano de 1853, no jornal Publicador Maranhense, consta anúncio do empresário Germano Francisco de Oliveira, que ocupava o São Luís, contendo os preços das assinaturas das récitas.

\footnotetext{
${ }^{3}$ A partir de 1920 o Teatro passa chamar Teatro Arthur Azevedo, sendo o segundo teatro mais antigo do Brasil em funcionamento desde o período colonial.
} 
Outros Tempos, vol. 18, n. 32, 2021, p. 220-247. ISSN: 1808-8031

Figura 2 - Theatro Nacional de S. Luiz

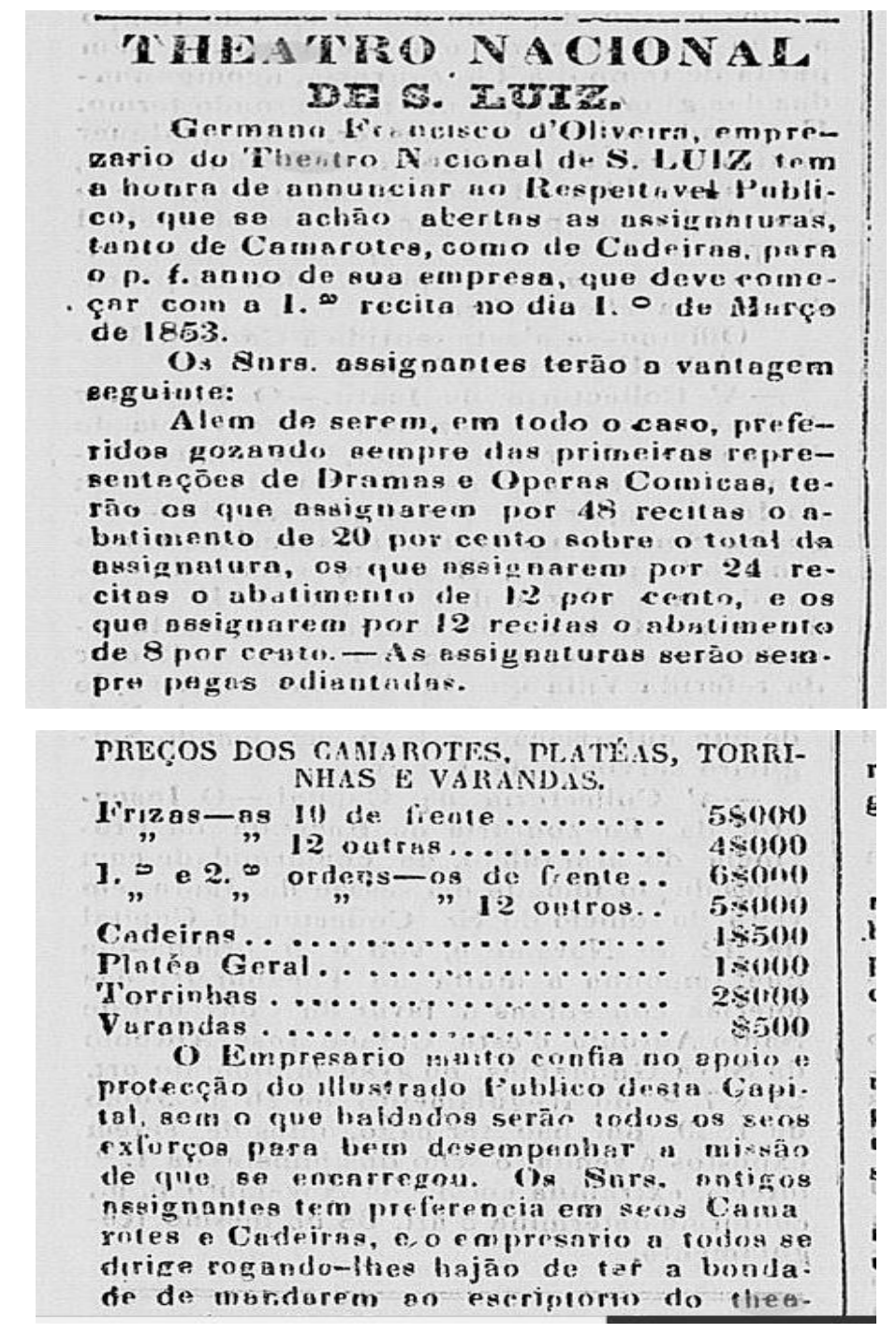

Fonte: Publicador Maranhense, ano 11, n. 1372, 25 fev. 1853. p. 4.

Ainda sobre a notícia fica claro o tipo de espetáculo que fazia sucesso, isto é, a ópera, pois “Ao pretender associar artes diversas, como música, poesia, cenografia, dança, [...] parece realmente buscar a mobilização do prazer estético através de diversos elementos" (FREIRE, 2010, p. 89). Ao longo do território brasileiro a ópera movimentou o Teatro São João, em Salvador (NEVES, 2000), o Teatro de Santa Isabel, em Recife (SILVA, 2006), o Teatro da Paz, em Belém, o Teatro Amazonas, em Manaus (DAOU, 2014), o Teatro São Pedro de Alcântara, o Teatro Imperial S. Pedro II, o Teatro S. Januário, o Teatro Lírico e o Teatro Lírico Fluminense, no Rio de Janeiro (FREIRE, 2013), e o Teatro São Carlos, em Campinas (NOGUEIRA, 2001). Nesse sentido, a capital maranhense não ficou de fora do roteiro das companhias líricas que se movimentavam pelo Brasil (GOUVEIA NETO, 2010). 
Outros Tempos, vol. 18, n. 32, 2021, p. 220-247. ISSN: 1808-8031

Ao longo dos anos seguintes, o Teatro São Luís continuou apresentando espetáculos líricos, conforme indica o jornal A Nova Epocha, que veiculou notícia sobre um em benefício dos artistas da Companhia Marinangeli.

\section{Comunicado}

O nosso Theatro ${ }^{4}$ vai ainda de quando em quando gemendo com concertos musicaes; e pelo beneficio, que se deu no sabbado á $\mathrm{Sr}^{\mathrm{a}}$ Condessa Maffei, a concorrencia do publico dez lembrar os dias felizes da Empreza.Todos sabem o triste desfecho d'esta Empreza; que deixou os artistas sem parte de seus estipendios ganhos com tantos sacrificios, e pontualidade no cumprimento de seus contractos, vendo-se alguns sem meios de regressarem á sua patria; em taes circunstancias forçoso era recorrer a um publico hospitaleiro e benevolo; por isso o Sr. Scandelari, primeiro Violino director da Orchestra segundo somos informados, obteve do Governo da Provincia a concessão de um beneficio, que em breve deve ter lugar. Excusado a recommendar agora protecção para o Sr. Scandelari a um publico illustrado amador da musica, que sempre se tem mostrado protector das bellas artes. Para tal beneficio se prestam gratuitamente seus compatriotas, a $\mathrm{Sr}^{\mathbf{a}}$ Condessa Maffei, Vanineti, Dalla Costa, e a $\mathrm{Sr}^{\mathrm{a}}$ Romagnelli, assim como a orchestra do mesmo Theatro 5 .

Já na década de 1860, é o empresário Vicente Pontes de Oliveira que ocupa o Teatro São Luís, como atesta anúncio publicado no jornal O Apreciavel, de 1867.

Figura 3 - Theatro

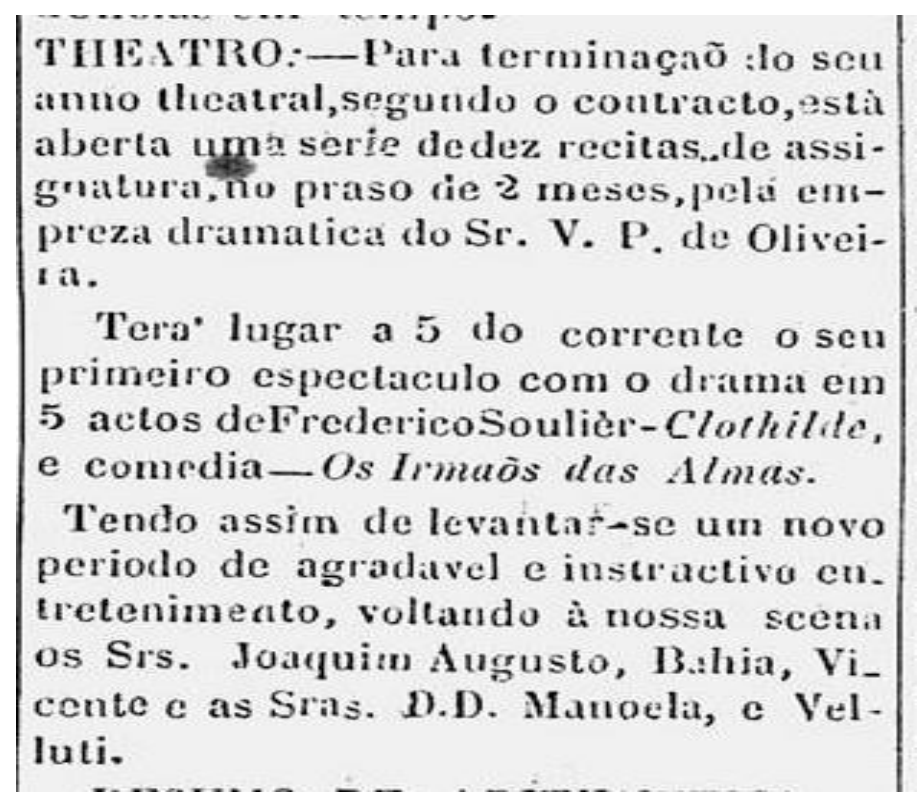

Fonte: $O$ Apreciavel, ano 2, n. 70, 2 nov. 1867. p. 4.

\footnotetext{
${ }^{4}$ As notícias são transcritas como no original.

${ }^{5}$ A Nova Epocha, ano 2, n. 106, 16 fev. 1858. p. 4.
} 
Outros Tempos, vol. 18, n. 32, 2021, p. 220-247. ISSN: 1808-8031

Nos anos seguintes, o Teatro São Luís passou por momentos de grande vibração e outros mais lentos, mas, constantemente, havia sons despontando por suas janelas, apesar da participação dos maranhenses, conforme indicou o jornal Pacotilha de 1897 (Figura 4), nem sempre corresponder às expectativas dos empresários do teatro. Uma causa da diminuição da presença das pessoas nos espetáculos líricos pode ser indicada pelo surgimento do cinema em São Luís, com sua instalação em um prédio em frente ao Teatro São Luís a partir de 1898 (MATOS, 2017).

Figura 4 - Concerto

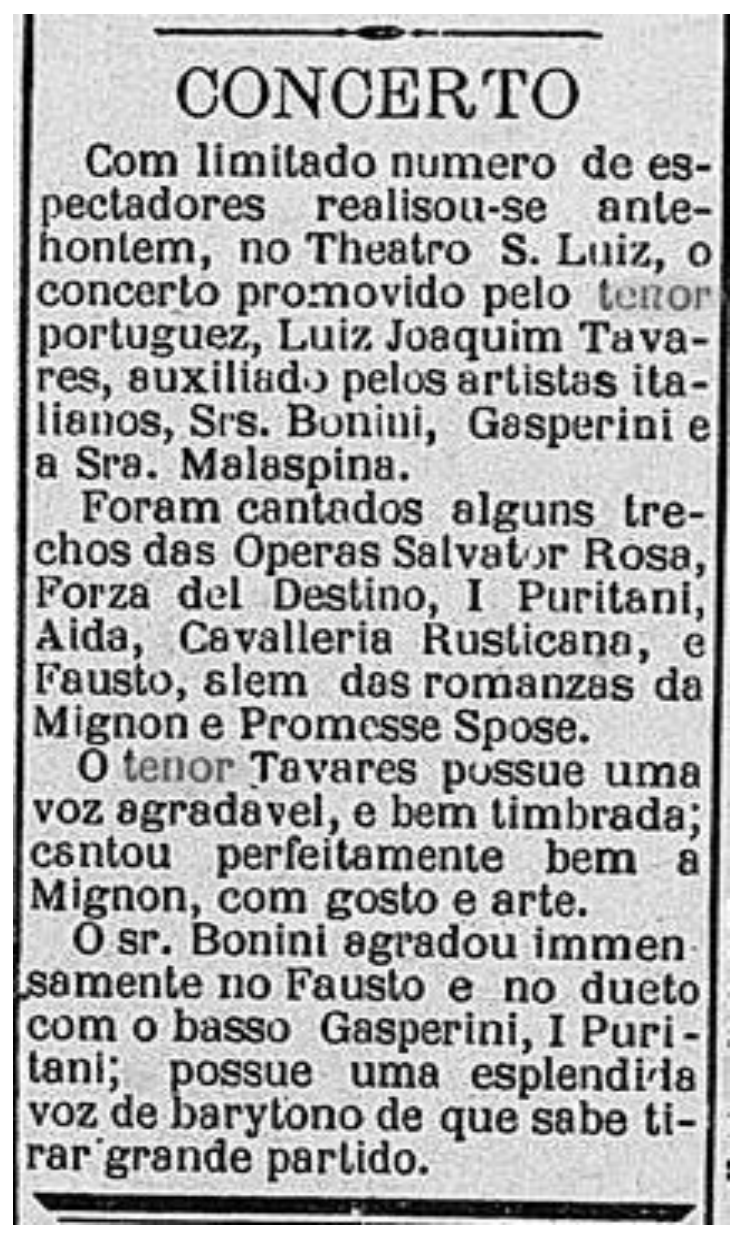

Fonte: Pacotilha, ano 17, n. 96, 26 abr. 1897. p. 2.

A notícia indica também a presença do repertório composto por árias de óperas entre as peças apresentadas no concerto, como Salvator Rosa, quinta ópera de Antônio Carlos Gomes (1836-1896), La forza del destino e Ainda, de Verdi (1813-1901), compostas respectivamente em 1862 e 1871, Il puritani, de Vicenzo Bellini (1801-1835), última ópera do compositor, apresentada em Paris com grande triunfo (SADIE, 1994, p. 91-92), Cavalleria 
Outros Tempos, vol. 18, n. 32, 2021, p. 220-247. ISSN: 1808-8031

rusticana, de Pietro Mascagni (1863-1945) e Fausto, de Charles Gounod (1818-1893), de 1859 (SADIE, 1994). Além do repertório consagrado, consta na notícia a presença de artistas europeus, no caso, italianos, na capital maranhense, hábito comum ao longo da segunda metade do século XIX em todo o Brasil.

Além dos espetáculos realizados no Teatro São Luís, nos clubes e nos teatros particulares, outro divertimento muito apreciado pelas elites eram os bailes, tão concorridos quanto os espetáculos teatrais e as festas realizadas em homenagem aos santos católicos, das quais tratarei em seguida. Assim como os espetáculos dados no Teatro, os bailes eram ocasiões nas quais a etiqueta e a civilidade era exercitada, pois "[...] tem como objetivo disciplinar o indivíduo, para que ele manifeste nos gestos, nas posturas e nas atitudes o primado absoluto das formas da vida social" (RAINHO, 2002, p. 99).

O Teatro São Luís era o grande palco dos maranhenses, mas não era somente em seus salões que os bailes se realizavam. As sociedades culturais particulares também os organizavam. E, nesses lugares, os pobres não tinham acesso "livre" como no teatro. As informações encontradas sobre essas celebrações de alegria coletiva não trazem especificidades sobre o baile e nem o preço das entradas. No jornal Publicador Maranhense, podemos observar o anúncio de baile no Club Maranhense.

Figura 5 - Club Maranhense

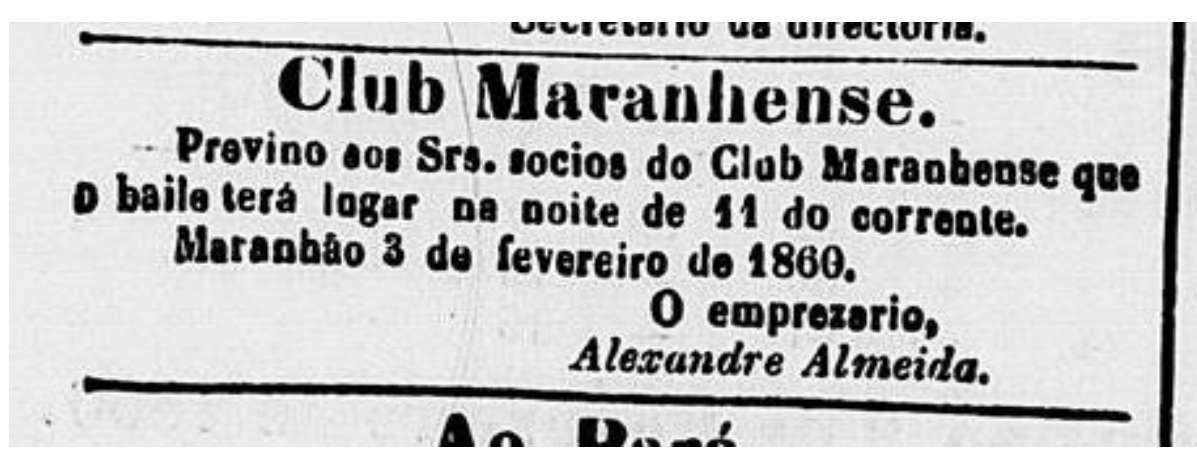

Fonte: Publicador Maranhense, ano 19, n. 32, 9 fev. 1860. p. 3.

A música executada nos salões onde os bailes aconteciam era de características ligeiras e foi de extrema importância para o desenvolvimento da música erudita no Brasil ao longo da segunda metade do século XIX, e de grande relevância para o estudo da formação da sociedade brasileira, pois essa "[...] música não foi só executada em soirées que incluíam a dança, mas [...] as próprias partituras impressas para piano representam danças da época, embora às vezes estilizadas ou abreviadas" (BISPO, 1999, p. 110). 
Outros Tempos, vol. 18, n. 32, 2021, p. 220-247. ISSN: 1808-8031

Ainda na década de 1860, mais um anúncio de baile no jornal Publicador Maranhense:

Figura 6 - Grandes Bailes

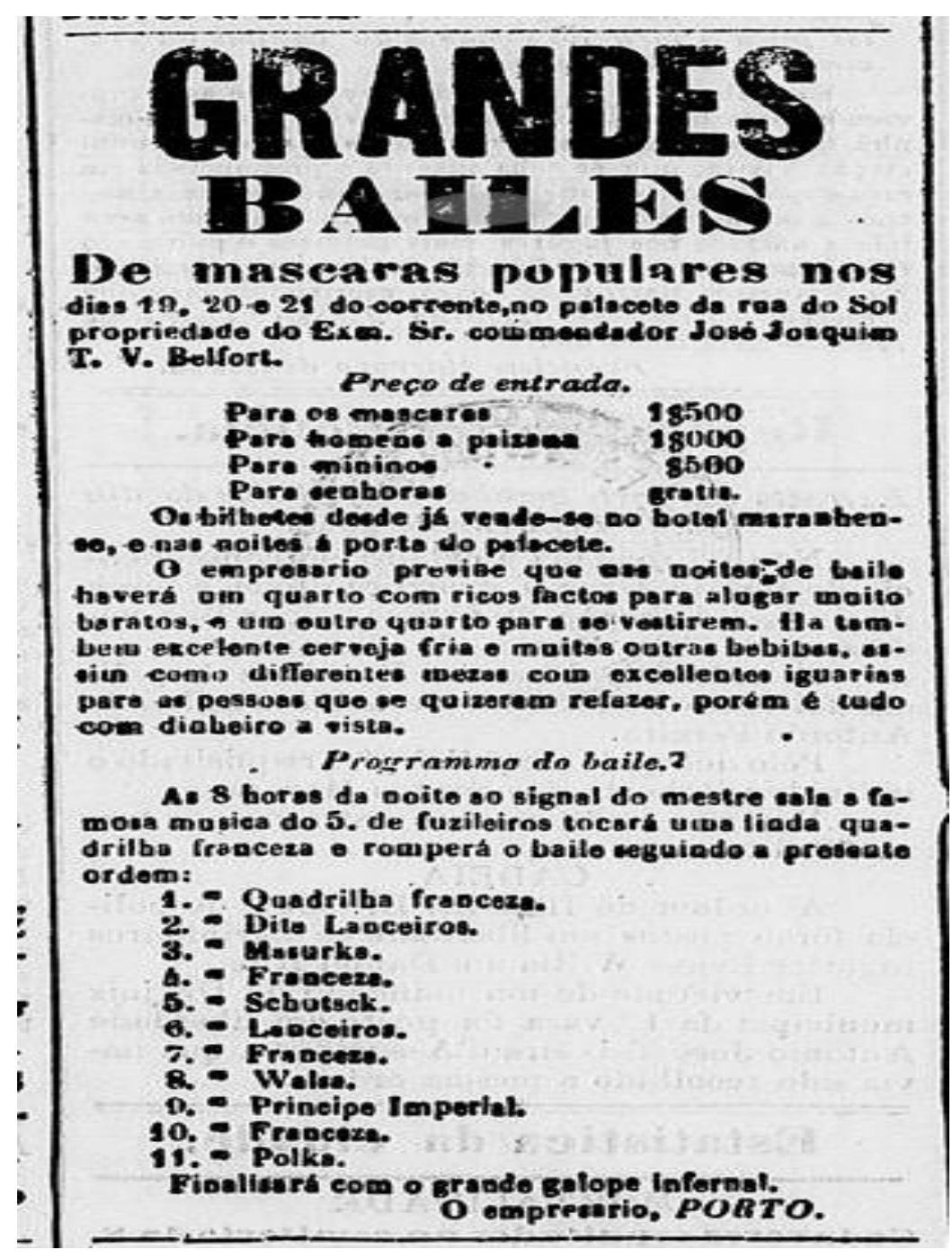

Fonte: Publicador Maranhense, ano 19, n. 40, 18 fev. 1860. p. 4.

A primeira questão a ser observada é o lugar onde esse baile se realiza, isto é, uma residência particular de um dos membros das elites da capital maranhense. A segunda diz respeito à música e sua importância, pois sem ela não haveria dança e, consequentemente, o divertimento. Além disso, o baile é um "[...] ambiente elegante, festivo e solene [...] É o espaço para a ostentação da posição social e da riqueza, onde se cultivam as relações convencionais e as etiquetas de salão" (FONSECA, 1996, p. 114), por isso, quando os promotores os anunciavam nos jornais faziam questão de frisar a elegância e a organização do salão onde o divertimento aconteceria. 
Outros Tempos, vol. 18, n. 32, 2021, p. 220-247. ISSN: 1808-8031

Outro ponto importante no que tange aos bailes é a dança. Os homens e as mulheres que a eles compareciam iam com o desejo de dançar. Por isso, a presença da música era imprescindível. No entanto, vale lembrar que na sociedade elitista do século XIX existia todo um protocolo para essas danças acontecerem, pois eram nessas ocasiões que os rapazes se aproximavam das moças. Apesar desse contato proporcionado entre casais pela dança durante o baile, não dava o direito de maiores liberdades com a dama, como adverte o manual de civilidade:

\begin{abstract}
A apresentação de uma senhora por occasião de um baile é para o único fim de dançar, e não dá jus ao cavalheiro, que lhe for apresentado, a ser recebido por essa senhora em sua casa. As relações assim entaboladas, terminam sempre com o baile. Se por casualidade vos encontrardes com uma senhora, com quem tiverdes dançado, não deveis dirigir-lhe a palavra: o mais que podeis fazer é tirar-lhe o chapêo; e isto mesmo só o fareis quando a distância, em que d'ella vos achardes, fôr tal que não passes evitar o aproximar-vos desta senhora (MANUAL DE CIVILIDADE, 1867, p. 91-92 apud MORAES, 2004, p. 33).
\end{abstract}

No entanto, independentemente do lugar onde os bailes aconteciam, o vestuário continuava sendo o mais elegante e refinado que as pessoas podiam apresentar, pois esses eventos eram considerados as reuniões mais solenes da sociedade, de modo que os cavalheiros deviam comparecer a eles "[...] com luvas brancas novas, gravata branca, colete branco, meia de seda e calça comprida ou pelo menos bota de polimento" (ROQUETTE, 1997, p. 158-159). As luvas simbolizavam requinte e elegância mostrada na forma como eram colocadas ou retiradas por homens e mulheres, pois as "[...] luvas francesas passaram a requinte ortodoxo no trajo feminino" (FREYRE, 1987, p.131).

Uma questão a ser mencionada em relação aos eventos anunciados nos jornais da capital maranhense é que eles não concorriam entre si, isto é, não aconteciam nas mesmas datas. Assim, nos meses das festas dedicadas aos santos católicos nada rivalizava com as programações organizadas para essas comemorações. Uma das festas mais comentadas na capital maranhense era a dedicada a Nossa Senhora dos Remédios, e meses antes os jornais estavam cheios de anúncios dos mais variados objetos indicados para a dita festa, isto é, chapéus, sapatos, roupas, visto que, era a santa padroeira dos comerciantes (OLIVEIRA, 2016).

A descrição mais minuciosa dessa festa foi realizada por João Francisco Lisboa, em forma de folhetim veiculado em 1851 no jornal Publicador Maranhense e editado por Jomar Moraes, em 1992. João Lisboa descreve inclusive o processo de preparação para a festa com a chegada "[...] dos navios que trazem no seu bojo os chapéus, as luvas, os vestidos, as 
Outros Tempos, vol. 18, n. 32, 2021, p. 220-247. ISSN: 1808-8031

quinzenas, as cassas, as sedas, as plumas, os cheiros, e todos os mais gêneros enfim dão vida e saúde às lojas, e entisicam as algibeiras dos fregueses [...]" (LISBOA, 1851 apud MORAES, 1992, p. 28). Já durante a festa, João Lisboa descreve a parte musical: "Rompe a música; o coro é dirigido pelo afamado maestro que de Lisboa acorreu às plagas americanas em busca de glória, distrações... e digamo-lo em honra da verdade, a composição e a execução são acabadas e primorosas como jamais se viu no Maranhão [...]” (LISBOA, 1851 apud MORAES, 1992, p. 36 -37). Sobre a importância da festa de Nossa Senhora dos Remédios, o jornal O Domingo, na coluna Notícias da Pacotilha, publicou o seguinte:

Quem é que hoje lê $O$ Domingo? Hoje, dia da festa de N. S. dos Remédios, a festa da moda e que atrahe inteiro o público pra si?" Quem é que deixa a grande missa do Miró ${ }^{6}$, o leilão, as manobras do 5. ${ }^{\circ}$, os bonds, o pau de sebo (!), a porfia dos pecadores e o agradável passeio no poético arraial, para entregar-se à leitura das Notícias da Pacotilha? Quem?...7

Assim como João Lisboa, o redator da notícia, além das colocações que ratificam a atenção dos ludovicenses para a festa dos Remédios, ao longo do texto descreve o que houve de melhor e de pior durante a festividade. Sobre a música escreve ainda: “Anachreonticas novenas, de anachreonticos músicos e música; arraial, onde se mostram divertimentos anachreonticos" $"$.

Ainda sobre a festa de Nossa Senhora dos Remédios, agora no ano de 1875, no jornal Diário do Maranhão, cujo anúncio da programação da festa foi assinado pelo secretário da irmandade, Jaime Candido de Freitas, ocupou quatro colunas de uma página do jornal, sendo inviável a inserção aqui. A seguir, na Figura 7, há uma parte da publicação.

\footnotetext{
${ }^{6}$ A Novena de Nossa Senhora dos Remédios, composta por Miró, faz parte das partituras do Acervo João Mohana, do Arquivo Público do Estado do Maranhão - APEM e pode ser consultada em: http://apem.cultura.ma.gov.br/acervo/search?query=novena+de+nossa+senhora+dos+rem\%C3\% A9dios\&query_ type=keyword\&record_types $\% 5 \mathrm{~B} \% 5 \mathrm{D}=$ Item\&record_types $\% 5 \mathrm{~B} \% 5 \mathrm{D}=$ File\&record_types $\% 5 \mathrm{~B} \% 5 \mathrm{D}=\mathrm{Collection}$ \&submit_search=Pesquisar

${ }^{7} O$ Domingo, ano 1, n. 36,13 out. 1872 . p. 1.

${ }^{8} O$ Domingo, ano 1, n. 36,13 out. 1872 . p. 1 .
} 
Outros Tempos, vol. 18, n. 32, 2021, p. 220-247. ISSN: 1808-8031

Figura 7 - Festividade de N. S. dos Remédios

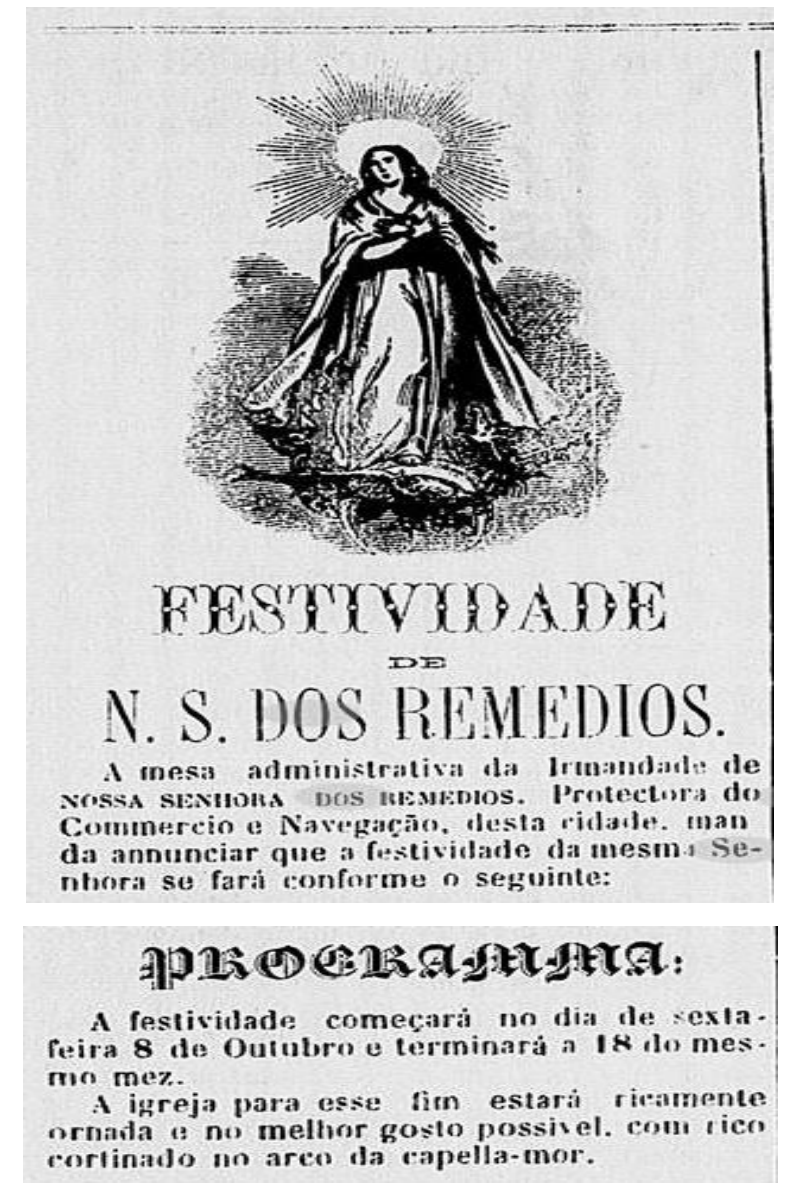

Fonte: Diário do Maranhão, ano 6, n. 644, 28 set. 1875. p. 4.

Além da parte propriamente religiosa, isto é, as novenas e missas, durante os dias de festa havia apresentação de bandas de música e, nessa edição do ano de 1875, a orquestra que tocou a novena composta por Luís Antônio Miró foi conduzida por Leocádio Rayol. Em todos os dias da programação houve participação de bandas de música, inclusive a da Casa dos Educandos Artífices ${ }^{9}$, assim como na do ano de 1851, descrita por João Lisboa, e o encerramento da festa se dava com a retirada da banda de música ${ }^{10}$.

O movimento para as festas religiosas continuou ao longo dos anos, como publicou imagem o jornal A Flecha em 1879, sobre a ida à festa de São José de Ribamar.

\footnotetext{
${ }^{9}$ Sobre a Casa dos Educandos Artífices, ver Castro (2007).

${ }^{10}$ Diário do Maranhão, ano 6, n. 644, 28 set. 1875. p. 4.
} 


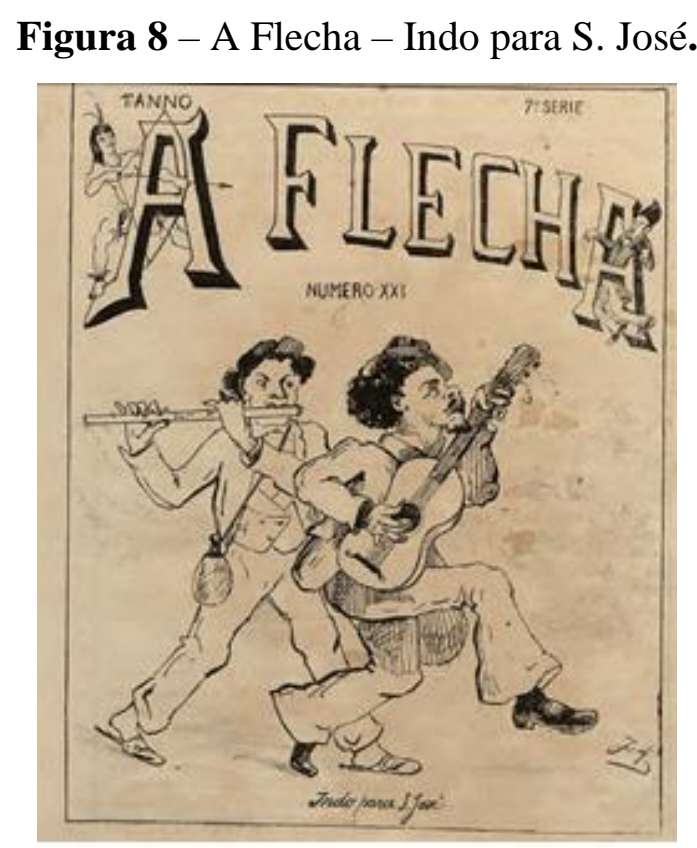

Fonte: A Flecha, ano 1, n. 21, 7. série, 1879.

\section{As partituras, os instrumentos e os professores que conduziam as vivências musicais nos jornais}

Outro indício da existência das vivências musicais em São Luís entre alguns membros das elites são os anúncios de venda de instrumentos musicais nos jornais da cidade. Ao longo do século XIX os instrumentos musicais fabricados não somente para acompanhar a voz humana, mas também para serem solistas, já estão bem desenvolvidos (BLANNING, 2011) e disseminados por todos os países do mundo. É evidente que existia grande dificuldade no transporte desses instrumentos, ainda mais quando se tratava dos pianos, mas estavam presentes no Brasil (ALENCASTRO, 1997, p. 45), assim como na capital maranhense, já na segunda década do século XIX (VIVEIROS, 1954, p. 379). Nos jornais que circulavam pela cidade diariamente, semanalmente, quinzenalmente eram frequentes os anúncios de venda de instrumentos de vários grupos ou famílias, como: instrumentos de cordas, de sopro, de percussão, de teclas ${ }^{11}$ e tudo o que fosse necessário para a boa utilização deles.

Sendo assim, é importante salientar que não havia em São Luís nenhuma organização comercial especializada e dedicada somente ao comércio musical no período em questão. Os instrumentos musicais eram oferecidos por livrarias, na melhor das hipóteses, e

\footnotetext{
${ }^{11}$ Sobre as subdivisões dos instrumentos musicais, ver Bennett (1998) e Ottó (2015).
} 
Outros Tempos, vol. 18, n. 32, 2021, p. 220-247. ISSN: 1808-8031

nos armazéns que vendiam gêneros diversos, como veiculou o jornal A Imprensa, como segue:

Figura 9 - Homeopathia

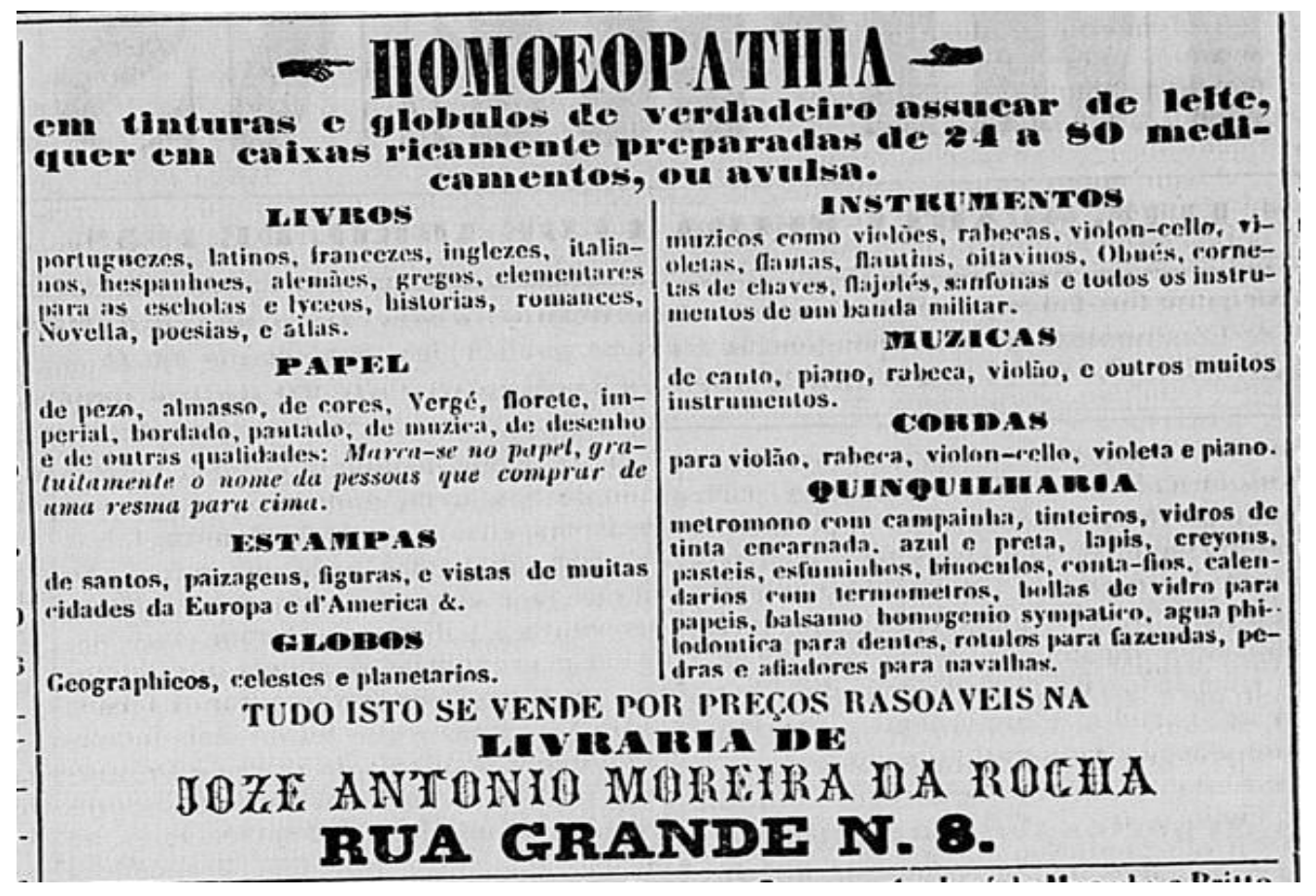

Fonte: A Imprensa, ano 2, n. 29,10 abr. 1858. p. 4.

O título principal do anúncio não remete em nada à música, mas na parte que trata dos instrumentos musicais fica claro a forte presença dos de sopro e, também, dos de percussão, pela indicação da formação de bandas militares. Além dos instrumentos musicais, José Antônio Moreira da Rocha também anunciava a venda de músicas, isto é, de partituras de canto, piano, rabeca e violão. O violão era denominado, por autores de notícias publicadas nos jornais, como instrumento de baderneiro e desocupado, mas que tinha a venda de cordas constantemente veiculadas nos jornais da cidade, como no anúncio do Publicador Maranhense: 
Figura 10 - Violões com caixa

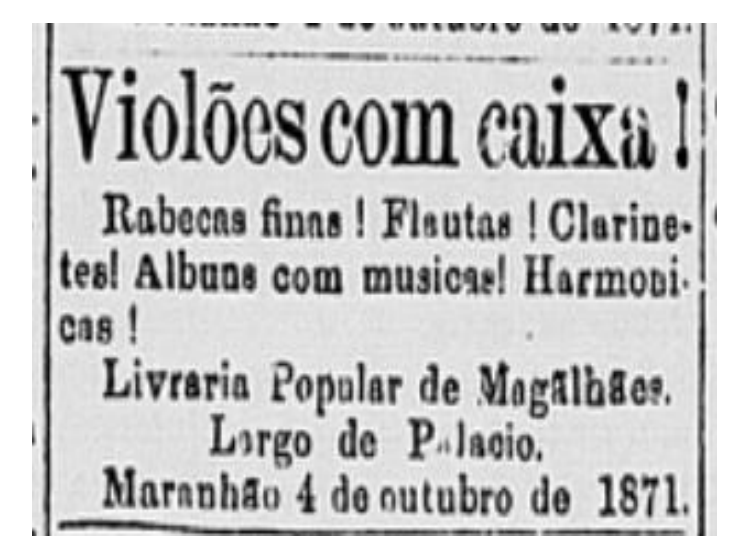

Fonte: Publicador Maranhense, n. 223, 11 out. 1871. p.3.

No entanto, os anúncios de venda de violão não correspondem à quantidade de cordas que são oferecidas aos maranhenses. Apesar desse dado, o jornal Publicador Maranhense veiculou notícia sobre a Exposição Maranhense de 1872, na qual está escrito que no Maranhão a fabricação de violões é importante, como segue:

A indústria da fabricação dos violões é relativamente importante no Maranhão, exportando-se muitos deles ao interior da Província e às províncias vizinhas. De todos os fabricantes, um só apresentou-se na Exposição, o Sr. Cláudio Antonio de Oliveira que concorreu com um cavaquinho que nos pareceu muito bem-feito. Se não nos enganamos, temos passado em revista todos os expositores, salvo um: o Sr. Fernando Antônio Corrêa que expôs um objeto do qual não nos lembramos, pedindo-lhe desculpas por essa falta involuntária. [...] Em resumo a Exposição Maranhense de 1872, sem ser mais concorrida que a de 1871, apresenta sobre a Província uma vantagem importante, que é o maior número de indústrias que foram representadas neste concurso de trabalhadores $[\ldots]^{12}$.

Essa notícia levanta duas questões importantes não só para o desenvolvimento da música no Maranhão, mas também em relação ao aperfeiçoamento das técnicas dos luthiers em São Luís e da indústria como um todo. É importante destacar que nas fontes levantadas esse é o único artigo que versa sobre indústria de violões. Talvez esse fato explique a grande quantidade de cordas que eram oferecidas nos jornais ludovicenses, como veiculado no jornal Pacotilha:

${ }^{12}$ Publicador Maranhense, s/n, 8 fev. 1873. p.2. 
Figura 11 - Cordas inglesas para violão e rabeca

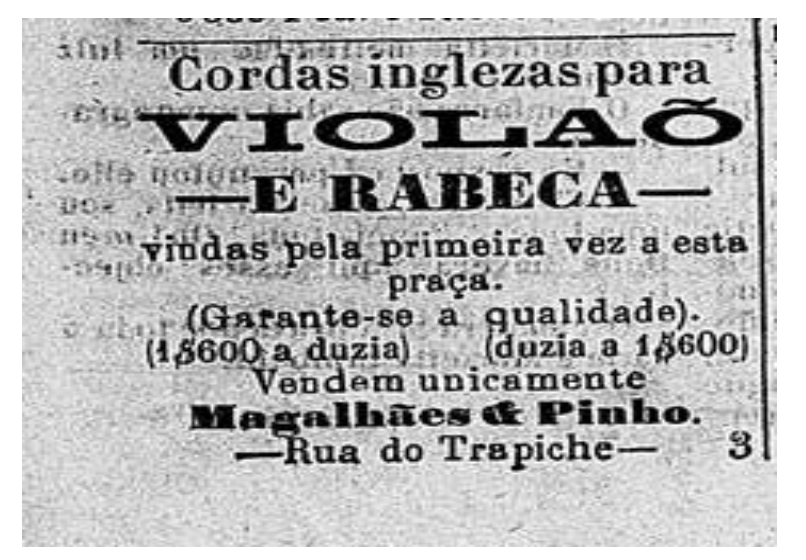

Fonte: Pacotilha, ano 4, n.222, 27 ago. 1884. p.1.

Os jornais em que estão as principais referências deste estudo, através dos seus anúncios traziam as ideias de mudança e progresso, assim como o gosto e as regras de civilidade (MONTEIRO, 2008, p. 76). Em relação aos artigos relacionados à música não será diferente. Com relação aos anúncios relacionados ao violão que venho analisando, a quantidade de anúncios de venda de cordas para o referido instrumento era superior aos demais artigos atrelados à música, como indica mais um anúncio a seguir: "Verdadeiras cordas para VIOLÃO. De seda e fita branca, Bordões de aço. Vendem - David, Rabello \& C. Rua da Palma. Livraria Americana"13.

Inversa era a quantidade de anúncios de pianos que apareciam nos jornais de São Luís. Essa "quantidade" é analisada aqui partindo do pressuposto de que um piano custava muito caro, pois vinha exclusivamente da Europa, apesar das fábricas existentes em Recife e no Rio Janeiro (ALENCASTRO, 1997, p. 46), o que encarecia ainda mais o seu preço por conta do transporte. No entanto, ao longo da segunda metade do século XIX, os anúncios de venda de pianos estavam presentes nos jornais da capital maranhense.

Outro ponto que ratifica a ideia de que o número de anúncios de piano era grande, considerando o fabricante, o preço e o custo do transporte da Europa para a América do Sul, é o fato de poucas pessoas terem conhecimentos musicais para executá-lo. No entanto, por conta da simbologia que envolvia esse instrumento, por vezes, o piano era adquirido como representação de refinamento, de distinção social e do poderio econômico da família que o apresentava em uma sala especialmente decorada (ALENCASTRO, 1997, p. 47).

${ }^{13}$ Diário do Maranhão, ano 30, n. 7875, 30 nov. 1899. p.4. 
Outros Tempos, vol. 18, n. 32, 2021, p. 220-247. ISSN: 1808-8031

Nos jornais de São Luís não eram anunciados apenas pianos novos. Pessoas físicas, por motivos que fogem ao conhecimento do pesquisador, colocavam seus pianos à venda, como consta no anúncio que foi veiculado no jornal Diário do Maranhão.

Figura 12 - Piano

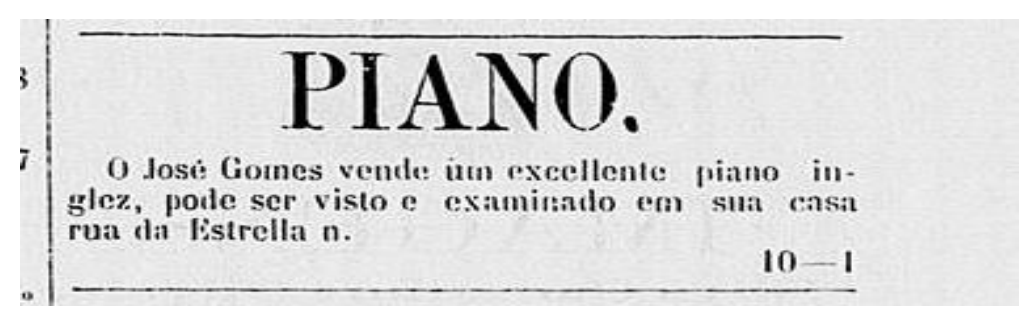

Fonte: Diário do Maranhão, ano 5, n. 376, 3 nov. 1874. p.3.

Além das categorias "pouco uso" e "bom estado", utilizadas para qualificar os pianos colocados à venda e que diminuíam os preços dos mesmos, existiam ainda os que serviriam para aprendizes, pois um pianista concertista não compraria um piano com essas qualificações, devido à falta de alguns atributos essenciais de afinação e resposta da tecla ao toque, que geralmente são mais irregulares nesses pianos. No entanto, instrumentos desse tipo eram oferecidos nos jornais, como se vê a seguir.

Figura 13 - Piano

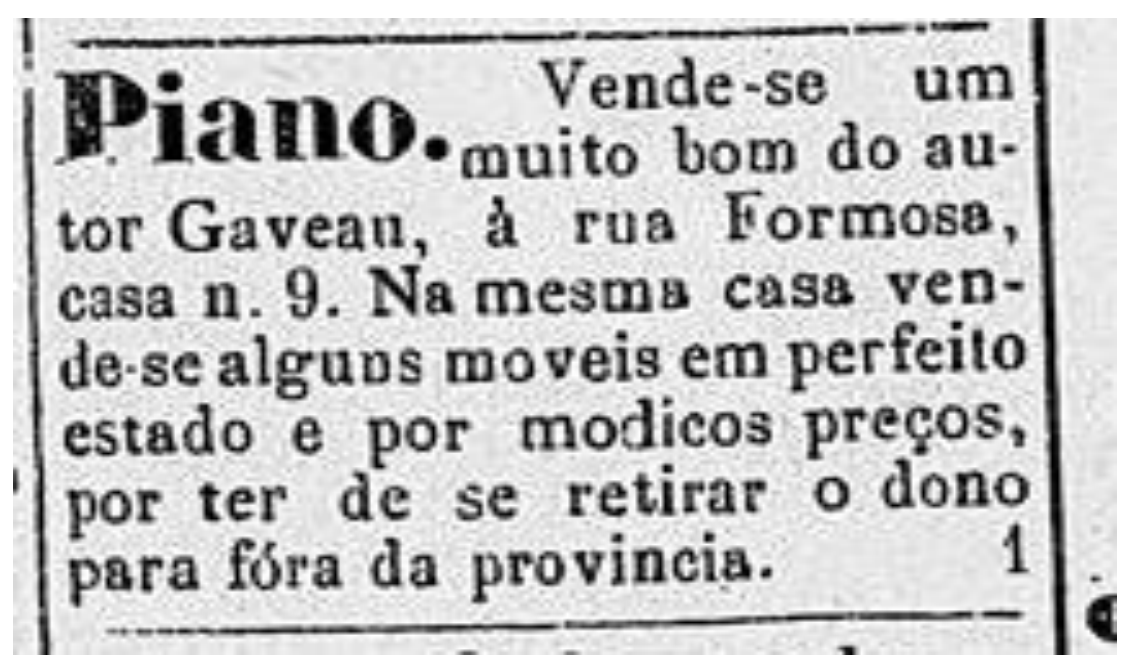

Fonte: Pacotilha, ano 4, n. 57, 1 mar. 1884. p. 1.

Geralmente, nesses anúncios de pianos usados vinham especificados “em bom estado", ou "com pouco uso", mas não vinha expresso o valor do instrumento, dado que ajuda a pensar se estava mesmo em bom estado, visto que, os pianos eram instrumentos musicais de 
Outros Tempos, vol. 18, n. 32, 2021, p. 220-247. ISSN: 1808-8031

alto valor econômico. O Diário do Maranhão assim anunciou: "Vende-se um baratíssimo na officina de Cypriano Baptista rua do Sol 19 podendo ser examinado por pessoa habilitada ou quem pretendel-o" 14 .

Vários tipos de instrumentos musicais eram postos à venda nos jornais, no entanto, os de maior ocorrência eram os pianos e os violões. Algumas possibilidades podem ser aventadas para a predominância de tais instrumentos, como no caso do piano, por ser o instrumento musical por excelência das elites, visto que era símbolo não só de refinamento como também de riqueza (ANDRADE, 2013), devido ao preço do instrumento e aos altos custos com o transporte da Europa ao Brasil, como já apontado. Já o violão possuía grande aceitação popular, valor aquisitivo menor e a presença da fábrica de violões citada anteriormente.

Além do piano, o órgão, mais solene e não menos refinado que o piano, aparecia nos anúncios também direcionado para quais lugares era mais apropriado, como diz a notícia:

Duchemin \& C. ${ }^{\text {a }}$ vendem:

Um orgão Harmonium proprio para sala ou para qualquer Igreja pequena preco de $400 \$ 000$.

PIANOS

Entre elles um grande de concerto, o melhor que ha nesta cidade e o mais seguro.

Binoculos para theatro, muito superiores e por preços moderados. Espelhos para salas. Diversos tamanhos com caixilhos dourados ${ }^{15}$.

Durante praticamente toda a segunda metade do século XIX, como ratifica o anúncio acima, São Luís careceu de uma livraria, loja ou comércio onde os músicos ou aspirantes a esse ofício pudessem encontrar em um só lugar o que necessitassem para os seus estudos. Apesar da maior representatividade do piano e do violão, os ludovicenses independentemente dos estratos sociais em que estavam inseridos, tinham acesso a outros tipos de instrumentos musicais. Dentre o universo dos instrumentos já disponíveis no período, a rabeca é um deles e era oferecida nos jornais da cidade, como no anúncio seguinte:

Despachado no 10 do corrente - Rabecas muito superiores com caixas, arcos para ditas igualmente superiores, resina e clina para os mesmos; tem a venda na Livraria de Antonio Pareira Ramos de Almeida, largo de Palacio, casa n.20. Vindo no vapor Parabé para a mesma Livraria: Arithmetica, Algebra e Geometria por Christiano Benedito Ottoni; Cathecismos da doutrina christã, aprovados pelo bispo do Rio de Janeiro. Julho de $1858^{16}$.

\footnotetext{
${ }^{14}$ Diário do Maranhão, ano 28, n. 7191, 21 ago. 1897. p.4.

${ }^{15}$ O Paiz, ano 2, n. 86, 26 jul. 1864. p.4.

${ }^{16}$ A Moderação, ano 2, n. 22, 31 jul. 1858. p.4.
} 
Outros Tempos, vol. 18, n. 32, 2021, p. 220-247. ISSN: 1808-8031

Ainda sobre a rabeca, mais um anúncio no jornal O Paiz: “Boa rabeca!!! Vende-se na rua Grande n. 119 uma muito boa rabeca sem uso nenhum, com methodo, por preço muito commodo" $" 17$.

Além dos instrumentos musicais, como os membros das elites utilizavam a música para diferenciarem-se dos seus iguais e, principalmente, dos músicos populares que tocavam de ouvido, geralmente utilizavam a partitura como principal elemento de orientação para execução da peça musical (ANDRADE, 2013). Por conta dessa necessidade dos músicos com a formação chamada hoje de erudita, os anúncios de venda de partituras eram constantes nos jornais. Logo nos primeiros anos da delimitação deste estudo e ano em que o Teatro São Luís é reaberto ao público maranhense, e, talvez por conta desse grande evento para o cenário cultural da capital da província do Maranhão, os jornais anunciavam as músicas novas, pois o consumo (ROCHE, 2000, p.76) precisa dessas estratégias para se movimentar.

Apesar dessa falta de especialidade no que se refere a um local dedicado somente aos artigos relacionados à música, os ludovicenses tinham a oportunidade de adquirir instrumentos e partituras musicais por meio desses comerciantes, como veiculou o Jornal do Commercio, em 1859.

Figura 14 - Vende-se

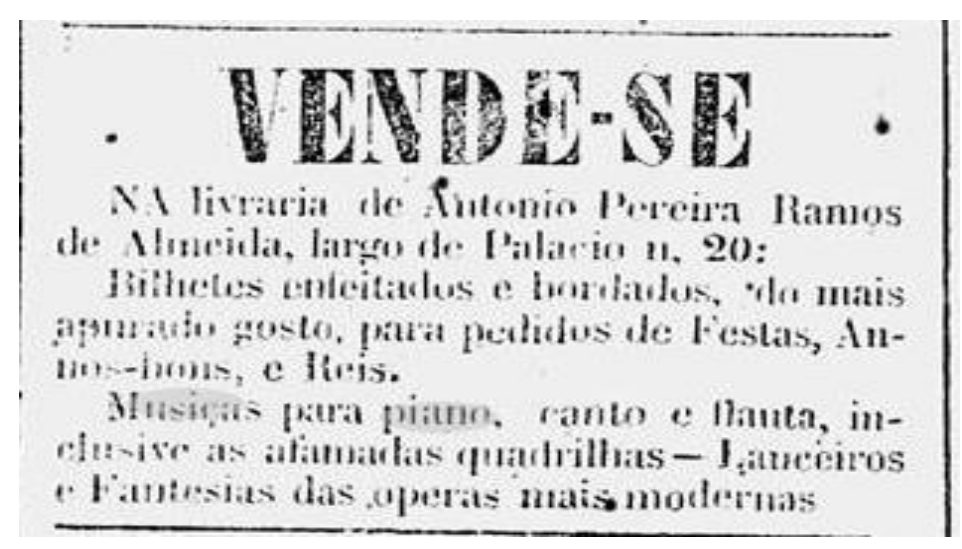

Fonte: Jornal do Commercio, ano 2, n. 162, 17 dez. 1859. p. 4.

Ainda na Livraria do Largo do Palácio, os ludovicenses podiam encontrar outras músicas para alegrar os dias de festa em suas residências e demais eventos que contavam com a música demarcando a movimentação das pessoas. A notícia a seguir não traz informações sobre os compositores das peças, mas indica que havia partituras à venda:

Musicas Novas

Moreninha, polk, londú, preco rs

600

${ }^{17}$ O Paiz, ano 11, n. 84, 14 jul. 1873, p.4. 
Outros Tempos, vol. 18, n. 32, 2021, p. 220-247. ISSN: 1808-8031

O Imperial marinheiro $\quad 1 \$ 200$

Garibaldi, quadrilha guerrense com todas as marcas $\quad 1 \$ 200$

Lanceiros novos $1 \$ 200$

Além d'estas há muitas d'outras qualidades; vendem-se na Livraria do Largo de Palacio, $20^{18}$.

Com o passar dos anos e uma consequente especialização do entendimento dos comerciantes no tocante à necessidade de chamar a atenção do possível comprador, os anúncios ficam mais explicativos e trazem mais informações para os estudiosos da música do século XIX maranhense, pois "[...] a imprensa musical foi se consolidando como um importante meio de difusão, de mediação cultural, de consagração de gêneros e estilos musicais e de formador de gostos musicais [...]" (LEME, 2010, p. 182), como escreve o redator do jornal Pacotilha:

Figura 15 - Músicas para piano

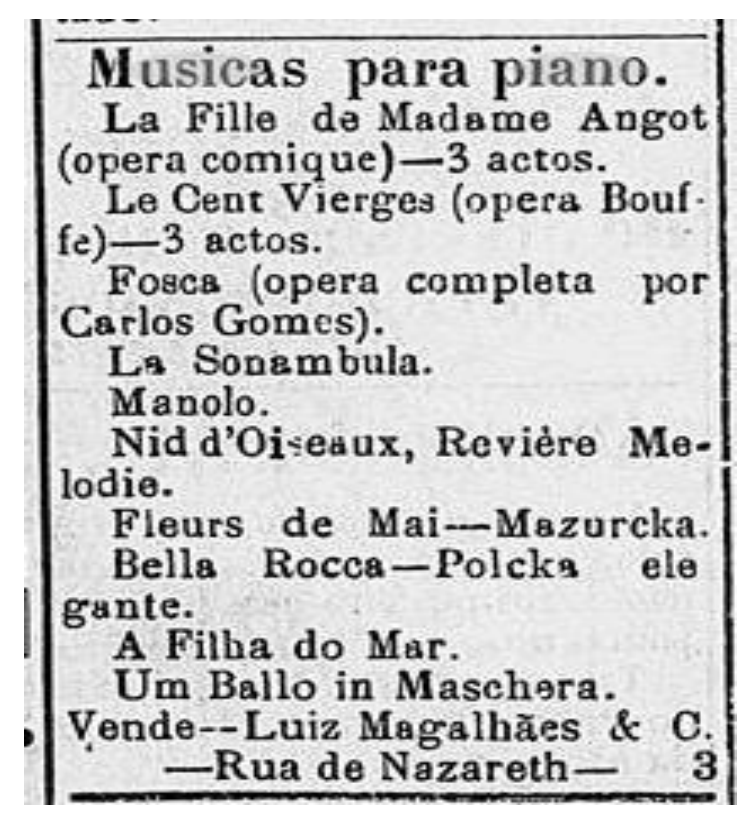

Fonte: Pacotilha, ano 4, n. 106, 22 abr. 1884. p.3.

As partituras estavam à venda, como relatam os jornais da capital maranhense, mas era necessário que as pessoas soubessem executar algum instrumento para usufruir das sensações que as mesmas ofereceriam ao serem ouvidas, pois a “[...] partitura é apenas um mapa, um guia para a experiência musical significativa, proporcionada pela interpretação e pela audição da obra" (NAPOLITANO, 2005, p. 84).

${ }^{18}$ A Imprensa, ano 6, n. 6, 22 jan. 1862. p. 4. 
Outros Tempos, vol. 18, n. 32, 2021, p. 220-247. ISSN: 1808-8031

Assim, os professores de música que residiam em São Luís colocavam à disposição dos interessados os seus conhecimentos no campo da música. Antônio Luiz Miró que foi regente da orquestra do Teatro São Luiz e era compositor conhecido nas plagas ludovicenses, também vendia partituras em sua residência e as reduzia da forma orquestral para qualquer instrumento solista, como veiculado no jornal Correio d'Annuncios:

Figura 16 - Antônio Luiz Miró

- Antonio Luiz Miró conıpositor de mu. sica, e professor de Piano e canto n'esta Capital, annuncia : que na caza de sua re sidencia na Rua Grande $n$. $^{\circ} 59$, se acha á venda uma grande porçao de musica pa ra Piano, a começar da mais facil athe á mais dificil, e para canto com accompanhamento de Piano; toda clla ultimamente ro. cebida da Luropa, e escolhida da mais moderna, e d'entre os melhores auctores Fran. ceaes, Alemaens, Italianos \&c. Tambem tem grante sortimento de musica de todos os generos para Banda Marcial: para grande e pequena orchestra : para canto com accompanhamento de orchestra ou Piano. Operas completas Francezas, Italiante, e Portuguezas com accompanhamentos de grnnde e pequena orchestra: musica sacra de diversos generos. Tambem tem uma collecęão de 12 valsas, das quaes 6 sāo com. posiçaó sua original n'esta capital, e se in. titulam-N. ${ }^{\circ} 1$ a sYmpatria. - N. 02 os AMOR ES. - N. O 3 o CrUARE. $-\mathrm{N}$. $\circ 4$ A DESPEDIDA. - N. ${ }^{\circ} 5$ a saudane. - N. 0 G O RE Gresso:- -as outrns 6 sáo extrahidas dè algumas das suas Oporas. Romances nm portugguez tambem de sua composiçấo \& c.\&. c. 


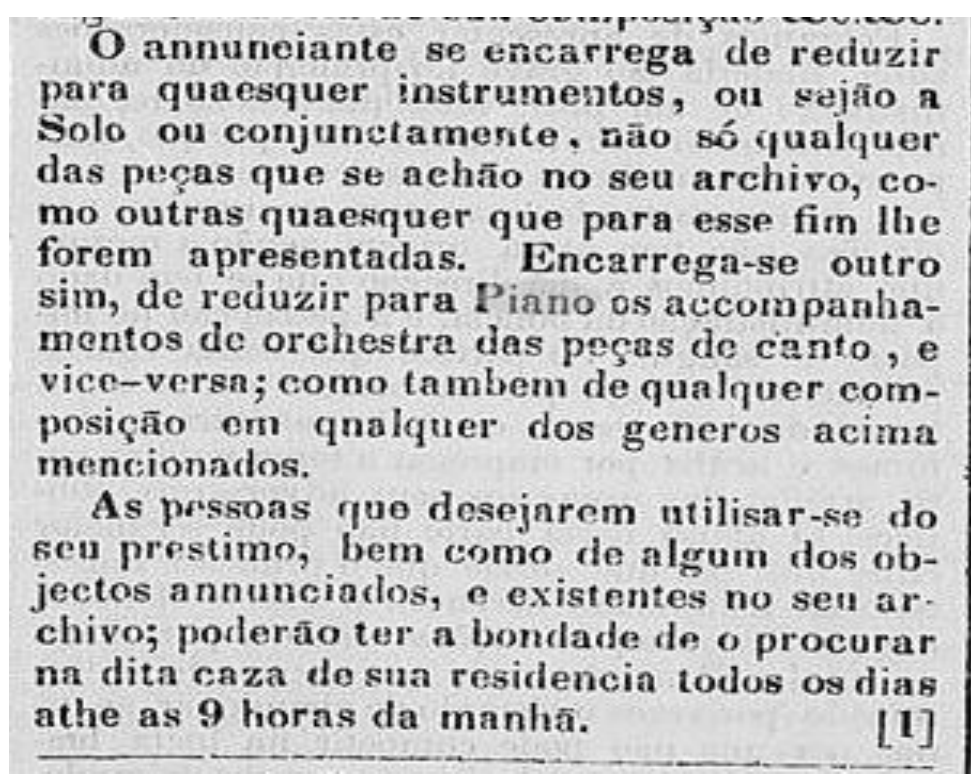

Fonte: Correio d'Annuncios, ano 1, n. 41, 17 jun.1851. p. 4.

Esse anúncio de Antônio Miró dá informação do tipo de qualificação que tinha o profissional de música que trabalhava em São Luís, pois além de professor de piano e canto reduzia qualquer partitura, de acompanhamento de orquestra, para piano. Esse é um dado importantíssimo, pois a escrita musical nem sempre vem atrelada à execução de um instrumento. Durante toda a história da música ocidental existiram compositores que, não necessariamente, eram exímios instrumentistas. Miró possuía uma formação musical muito sólida e completa pela quantidade de serviços que oferecia ao público maranhense.

Algumas dessas pessoas que anunciavam a venda de música nos jornais geralmente estavam ligadas ao mundo das notas e dos sons. Bernardino do Rego Barros, que fez publicar anúncio de venda de partitura no jornal A Imprensa, anuncia que “[...] dá lições de Flauta e Clarineta por casas particulares"19.

No entanto, não era somente o piano que era privilegiado com a existência de professores para os que desejam se dedicar à técnica pianística. Os instrumentos de percussão também podiam ser aprendidos por quem assim quisesse, pois anunciava o jornal Porto Livre:

Aos Caixeiros amantes da musica

O abaixo assignado lecciona em casa do Sr. Domingos da Silva Sampaio, rua do Giz - Musica em instrumentos bellicos, - das 7 as 9 horas da noute, sendo nas Segundas, Quartas e Sextas-feiras.

Aquellas pessoas que se quizerem utilizar do prestimo do mesmo, podem procura-lo na dita casa as horas já indicadas. Leocadio Ferreira de Souza ${ }^{20}$.

\footnotetext{
${ }^{19}$ A Imprensa, ano 5, n. 43, 1 jun. 1861. p.4.

${ }^{20}$ Porto Livre, ano 1, n. 26, 1862. (Mutilado).
} 
Outros Tempos, vol. 18, n. 32, 2021, p. 220-247. ISSN: 1808-8031

É importante destacar a quantidade de músicos profissionais existentes em São Luís na segunda metade do século XIX. Isso não quer dizer que todos esses músicos tinham domínio dos conhecimentos teóricos musicais, pois não é necessário saber ler partitura para executar um instrumento de sopro, de cordas, de percussão, para cantar ou mesmo para o piano. O estudo musical dirigido dá a possibilidade de esses instrumentos serem mais bem utilizados e seus recursos potencializados.

Ao mesmo tempo em que esses músicos anunciavam seus serviços de copista de partituras, é importante pontuar que essas músicas anunciadas nos jornais são músicas somente para quem tinha algum conhecimento de leitura musical, pois, naquela segunda metade do século XIX, não existiam os recursos sonoros de gravação disponibilizados atualmente. Então, somente a família que tinha algum estudante ou "curioso" no campo musical podia usufruir dessas novas músicas, pois: “[...] a música, enquanto escritura, notação da partitura, encerra uma prescrição, rígida no caso das peças eruditas, para orientar a performance. Mas a experiência musical só ocorre quando a música é interpretada" (NAPOLITANO, 2005, p. 83-84).

Para todos os instrumentos anunciados nos jornais era preciso de profissionais que cuidassem da conservação dos mesmos. No entanto, somente os afinadores de pianos colocavam seus préstimos à disposição dos ludovicenses. Essa presença dos afinadores nas páginas dos jornais pode ser entendida devido à especialização que esse profissional deveria possuir e pela clientela que precisava de seus préstimos e podia pagar pelos serviços. No jornal O Observador João Evangelista do Livramento "[...] faz publico que se acha habilitado para afinar pianos; offerece portanto, o seu préstimo á aquellas pessoas que o quizerem obzequiar com sua protecção. Pode ser procurado em sua caza na rua de Sant'Anna n. 44, mística a que mora o Sr. Dr. Ferrão"21.

\section{Considerações finais}

Pensar sobre as vivências musicais no século XIX sem relacioná-las à imprensa, em especial, aos jornais, é uma atividade que trará poucos resultados e será muito difícil de ser empreendida, pois não há outros documentos que deem tantas informações sobre músicos, professores de música, instrumentos musicais, espetáculos dados nos teatros, festas religiosas, bailes e tantos outros eventos. Para conhecer um pouco da escrita musical as partituras são

\footnotetext{
${ }^{21}$ O Observador, ano 8, n. 408, 6 jun.1855. p. 4.
} 
Outros Tempos, vol. 18, n. 32, 2021, p. 220-247. ISSN: 1808-8031

extremamente relevantes, mas em termos de conhecimento cultural aprofundado e discutido sobre o século XIX, essas fontes não se bastam sozinhas.

Neste artigo constam alguns exemplos da potencialidade dos anúncios e notícias que os jornais trazem sobre as vivências musicais na capital maranhense. As informações contidas nessas fontes atestam a inserção do Maranhão nos ditames dos modelos de divertimentos elegantes europeus indicados pelos espetáculos realizados nos teatros, os bailes e tipo de música que era consumido na dita capital, assim como em outras partes do Brasil.

Como apontado ao longo deste texto, era através dos anúncios e notícias publicados nos jornais que os ludovicenses eram informados e conduzidos sobre o tipo de música que deviam ouvir e sobre a necessidade de participar das vivências musicais que aconteciam pela cidade de São Luís em espaços públicos, como os largos onde aconteciam as festas em comemoração aos santos católicos, assim como nos espaços que necessitavam de pagamento para deles participarem.

Assim, através dos anúncios e notícias publicados nos jornais, é possível ouvir as melodias das árias das óperas, os acordes formados pelo violão e pelo piano, assim como pelas orquestras que animavam e sensibilizavam os ludovicenses nas noites quando as luzes dos teatros, dos bailes e dos largos das igrejas estavam acesas, indicando a efetivação das vivências musicais na capital maranhense.

\section{Referências}

\section{Documentos}

A Flecha, ano 1, n. 21, 7. série, 1879.

A Imprensa, ano 2, n. 29, 10 abr. 1858.

A Imprensa, ano 5, n. 43, 1 jun. 1861.

A Imprensa, ano 6, n. 6, 22 jan. 1862.

A Moderação, ano 2, n. 22, 31 jul. 1858.

A Nova Epocha, ano 2, n. 106, 16 fev. 1858.

Correio d'Annuncios, ano 1, n. 41, 17 jun. 1851.

Diário do Maranhão, ano 5, n. 376, 3 nov. 1874.

Diário do Maranhão, ano 6, n. 644, 28 set. 1875. 
Outros Tempos, vol. 18, n. 32, 2021, p. 220-247. ISSN: 1808-8031

Diário do Maranhão, ano 28, n. 7191, 21 ago. 1897.

Diário do Maranhão, ano 30, n. 7875, 30 nov. 1899.

Jornal do Commercio, ano 2, n. 162, 17 dez. 1859.

O Apreciavel, ano 2, n. 70, 2 nov. 1867.

O Domingo, ano 1, n. 36, 13 out. 1872.

O Observador, ano 8, n. 408, 6 jun. 1855.

O Paiz, n. 86, 26 jul. 1864.

O Paiz, n. 84, 14 jul. 1873.

Pacotilha, ano 4, n. 57, 1 mar. 1884.

Pacotilha, ano 4, n. 106, 22 abr. 1884.

Pacotilha, ano 4, n. 222, 27 ago. 1884.

Pacotilha, ano 17, n. 96, 26 abr. 1897.

Porto Livre, ano 1, n. 26, 1862.

Publicador Maranhense, ano 8, n. 9817, 7 mar. 1850.

Publicador Maranhense, ano 11, n. 1372, 25 fev. 1853.

Publicador Maranhense, ano 19, n. 32, 9 fev. 1860.

Publicador Maranhense, ano 19, n. 40, 18 fev. 1860.

Publicador Maranhense, n. 223, 11 out. 1871.

Publicador Maranhense, s/n, 8 fev. 1873.

\section{Bibliografia}

ALENCASTRO, Luiz Felipe. Vida privada e ordem privada no Império. In: ALENCASTRO, Luiz Felipe (org.). História da vida privada no Brasil: Império. São Paulo: Companhia das Letras, 1997. p. 11-93.

ANDRADE, Clarissa Lapolla Bomfim. A Gazeta Musical: positivismo e missão civilizadora nos primeiros anos da República no Brasil. São Paulo: Editora Unesp, 2013.

BARROS, José D’Assunção. Fontes históricas: introdução aos seus usos historiográficos. Petrópolis, RJ: Vozes, 2019. 
Outros Tempos, vol. 18, n. 32, 2021, p. 220-247. ISSN: 1808-8031

BENNETT, Roy. Elementos básicos da música. Tradução de Maria Teresa de Resende Costa. Rio de Janeiro: Zahar, 1998.

BISPO, A. A. Brasil/Europa \& Musicologia: aulas, conferências e discursos. Köln: A.B.E; I.S.M.P.S.; I.B.E. M., 1999 (Anais de Ciência Musical).

BLANNING, Tim. O triunfo da música: a ascensão dos compositores, dos músicos e de sua arte. Tradução de Ivo Korytowski. São Paulo: Companhia das Letras, 2011.

CASTRO, Cesar Augusto. Infância e trabalho no Maranhão provincial: uma história da casa dos Educandos Artífices (1841-1889). São Luís: EdFUNC, 2007.

CHARTIER, Roger. A história cultural: entre práticas e representações. Tradução de Maria Manuela Galhardo. Lisboa: Difel, 1990.

DAOU, Ana Maria. A cidade, o teatro e o "Paiz das seringueiras": práticas e representações da sociedade amazonense na passagem do século XIX - XX. Rio de Janeiro: Rio Book's, 2014.

FONSECA, Aleilton. Enredo romântico, música ao fundo. Rio de Janeiro: Sette Letras, 1996.

FREIRE, Vanda Bellard. Música e sociedade: uma perspectiva histórica e uma reflexão aplicada ao ensino superior de Música.2.ed. Florianópolis: Associação Brasileira de Educação Musical, 2010.

FREIRE, Vanda Bellard. Rio de Janeiro, século XIX: cidade da ópera. Rio de Janeiro: Garamond, 2013.

FREYRE, Gilberto. Modos de homem \& modas de mulher. Rio de Janeiro: Record, 1987.

GOUVEIA NETO, João Costa. Ao som de pianos, flautas e rabecas... estudo das vivências musicais das elites na São Luís da segunda metade do século XIX. 2010. 168f. Dissertação (Mestrado em História do Brasil) - Universidade Federal do Piauí, Teresina, 2010.

JANSEN, José. Teatro no Maranhão. Rio de Janeiro: [s. n.], 1974.

LEME, Mônica Neves. Cancioneiros populares para Ioiôs e Iaiás: o mercado editorial para a "música ligeira" no Rio de Janeiro (1870-1920). In: MARZANO, Andrea; MELO, Victor Andrade de (org.) Vida divertida: histórias do lazer no Rio de Janeiro (1830-1930). Rio de Janeiro: Apicuri, 2010. p. 179-210.

LUCA, Tania Regina de. História dos, nos e por meio dos periódicos. In: PINSKY, Carla Bassanezi (org.). Fontes históricas. 2. ed., 1. reimp. São Paulo: Contexto, 2008. p. 111-153.

MARQUES, César Augusto. Dicionário histórico-geográfico da província do Maranhão. 3. ed. Rio de Janeiro: Cia Editora Fon-Fon e Seleta, 1970.

MATOS, Marcos Fábio Belo. José Fillipi: o italiano pioneiro do cinema no Maranhão. Revista Brasileira de História da Mídia, v. 6, n. 1, p. 197-213, jan./jun. 2017. 
Outros Tempos, vol. 18, n. 32, 2021, p. 220-247. ISSN: 1808-8031

MONTEIRO, Maurício. A construção do gosto: música e sociedade na corte do Rio de Janeiro 1808 - 1821. São Paulo: Ateliê Editorial, 2008.

MORAES, Darlen Cristina Sousa de. Novo de civilidade ou regras para qualquer pessoa frequentar a boa sociedade: um breve comentário. 2004. Monografia (Graduação em História) - Universidade Federal do Maranhão, São Luís, 2004.

MORAES, Jomar (ed.). A festa de Nossa Senhora dos Remédios. São Luís: Editora Legenda, 1992.

NAPOLITANO, Marcos. História \& Música. Belo Horizonte: Autêntica, 2005.

NEVES, Maria Helena Franca. De la traviata ao maxixe: variações estéticas da prática do Teatro São João. Salvador: SCT/ FUNCEB/ EGBA, 2000.

NOGUEIRA, Lenita Waldige Mendes. Música em Campinas nos últimos anos do Império. Campinas, SP: Editora da Unicamp; CMU, 2001.

OLIVEIRA, Milena Rodrigues de. Manifestações da fé católica: um estudo sobre as festas de Nossa Senhora dos Remédios, Nossa Senhora da Conceição e Nossa Senhora do Rosário em São Luís (1850 - 1875). 2016. 106f. Dissertação (Mestrado em História Social) Universidade Federal do Maranhão, São Luís, 2016.

OLIVEIRA, Rodrigo Santos de. A relação entre história e imprensa, breve história da imprensa e as origens da imprensa no Brasil (1808 - 1930). Historiae, Rio Grande, v. 2, n. 3 , p. 125-142, 2011.

OTTÓ, Károlyi. Introdução à música. Tradução de Álvaro Cabral. 2. ed. São Paulo: Martins Fontes, 2015.

RAINHO, Maria do Carmo Teixeira. A cidade e a moda: novas pretensões, novas distinções Rio de Janeiro, século XIX. Brasília, DF: Editora da Universidade de Brasília, 2002.

ROCHE, Daniel. História das coisas banais: nascimento do consumo nas sociedades do século XVII ao XIX. Tradução de Ana Maria Scherer. Rio de Janeiro: Rocco, 2000.

ROQUETTE, J. I. Código do bom-tom, ou, regras da civilidade e de bem viver no século XIX. São Paulo: Companhia da Letras, 1997.

SADIE, Stanley. Dicionário Grove de música. Tradução de Eduardo Francisco Alves. Rio de Janeiro: Jorge Zahar Ed., 1994.

SILVA, José Amaro Santos da. Música e ópera no Santa Isabel: subsídio para a história da música no Recife. Recife: Ed. Universitária da UFPE, 2006.

VIVEIROS, Jerônimo de. História do comércio do Maranhão (1612-1895). São Luís: Associação Comercial do Maranhão, 1954. v. 2. 